\title{
Professional learning through collaborative research in mathematics
}

\section{Diane Dalby}

School of Education

University of Nottingham

Jubilee Campus

Wollaton Road

Nottingham

NG8 1BB

01157484392

diane.dalby@nottingham.ac.uk

Orcid ID 0000-0002-1603-6206

Diane is a Senior Research Fellow at the University of Nottingham. She has extensive experience of teaching mathematics and worked in education management before undertaking doctoral study. Her research interests focus on policy and practice within mathematics education, particularly in the Further Education sector. 


\section{Professional learning through collaborative research in mathematics}

In this study, the professional learning of two groups of secondary mathematics teachers are compared as they participate in an education research project to explore the uses of iPads within formative assessment processes. Data from lesson observations, meetings and teacher interviews show how collaborative participation in a design research cycle involving the development, implementation and analysis of lessons facilitated individual and collective professional learning. Specific elements of the design research process provided opportunities for knowledge sharing and reflection on practice, but individual learning gains were closely associated with the development of these teacher groups into professional learning communities. Two contrasting case studies show how various affordances and constraints of the research activity either encourage or restrain the development of characteristics associated with professional learning communities. The findings provide insight into the early developmental stages of professional learning communities, the conditions that affect their growth and the efficacy of collaborative design research to stimulate the development of such communities.

Keywords: teacher development; professional learning communities; collaborative research; mathematics education.

\section{Introduction}

Professional development has frequently been perceived to be an essential element of school improvement or national reform (Guskey, 1994, Villegas-Reimers, 2003) and it is a common assumption that changing teacher practice is crucial to raising and maintaining standards (Day and Sachs, 2004). Whether professional development is an effective instrument in the change process is debatable but on-going international interest suggests its increasing importance (Fraser et al., 2007). Consequently, attention has turned to the effectiveness of different models (Kennedy, 2005, 2016). In countries such as England, high-stakes performance measures bring the quality of teaching in the classroom under close scrutiny and the search for effective professional development is 
a priority. From the perspective of an individual teacher though, professional development forms part of an on-going process towards maturity as a skilled professional. Much is demanded, therefore, from professional development activity as a means of facilitating change in systems, schools and the classroom practice of individual teachers (Cochran-Smith and Zeichner, 2009).

One of the difficulties in this search for effectiveness is uncertainty about how teacher practice can be improved. A recent shift in research interest away from short instructional events focussed on the individual, reflects trends in approaches to learning towards participation rather than acquisition (Matos et al., 2009) and evidence that traditional strategies, based on the assumption that theoretical learning about classroom teaching will result in changes to practice, are ineffective (Cochran-Smith and Zeichner, 2009). There has been increasing interest in practice-based approaches involving collaborative activity within teacher groups rather than a 'top down' instructional approach (Stoll et al., 2006, Matos et al., 2009) and an emphasis on the professional learning gained from reflection on workplace activity in the light of relevant theory (Avalos, 2011). This emphasis on collaborative teacher groups as a model for professional learning has led to much debate about how such teacher groups can form effective and sustainable professional learning communities with the ability to develop and change practice (Vescio et al., 2008). Despite variations in the meaning attributed to this term, which are discussed later, the characteristics of professional learning communities are well-documented (Cochran-Smith and Lytle, 1999, Bolam et al., 2005, Stoll et al., 2006, Vescio et al., 2008, DuFour and Eaker, 2009, O.E.C.D., 2013). Less attention seems to have been paid, however, to how groups of teachers actually develop and grows into communities with these characteristics. 
In this paper the changes in individual and socially shared professional knowledge within two teacher groups will be examined as they engage in a collaborative design research project with university researchers over a period of about nine months. These were school-based trios of mathematics teachers who volunteered to participate in the research. Each group of three worked together in the same school department. These trios were supported by university researchers who acted as facilitators of group activity, co-designers and observers with both an insider role in the design of lessons but also acted as an outsider to observe and evaluate. Since these are localised time-bound cases we will be concerned with the professional learning that takes place, rather than the longer-term development of professionals at school or system level (Fraser et al., 2007).

The overall aim of this paper is to understand how involvement in this type of collaborative research affects the professional learning of the teachers involved. By studying the development of these teacher groups, the first objective is to identify the group characteristics that emerge and secondly their similarity, or otherwise, to features of a professional learning community. Finally the conditions for growth of these characteristics will be examined, from which conclusions will be drawn about the ways in which participation in collaborative research can provide favourable conditions for the development of these features.

The study focuses on addressing the following research questions:

- How does participation in the collaborative research project affect teachers' individual and collective professional learning?

- What characteristics of a professional learning community emerge during participation in the research activity? 
- What elements of the design research activity, or other contextual factors, are instrumental in the development of these characteristics?

By focussing on two small case studies of teacher groups in similar schools who are participating in the same design research project, the study allows the actions and interactions of the participants to be examined in depth during the development stage of these groups and detailed cross-case comparisons to be made.

This study of professional learning takes place within a national context in England where the profile of teacher-led research has been raised over recent years. Whilst agreeing with the value of participation in research for teachers, the promotion of a wholly teacher-centric approach seems to overlook the synergy generated from collaborative partnerships of professionals with complementary roles, knowledge and expertise. As Slavit and Nelson's (2010) case study suggests, teachers benefit from working in collaborative inquiry to improve their practice. Collaboration that involves both teachers and researchers may, however, have additional benefits since this involves a combination of different experiences and knowledge with the potential to stimulate deeper inquiry into teachers' on-going examination of their own classroom practice.

\section{Research context}

Although the primary concern in this paper is the professional learning facilitated through teacher participation in a collaborative design research project, it is also necessary to consider the specific context in which this takes place. Professional learning is viewed here as a socially situated experience and the nature of the design research project contributes to the construction of a social space in which this learning takes place. From this perspective, there are two particular aspects of this project that need to be considered: the design process and the specific aims of the design project. 


\section{The design process}

The lesson design process involves a cycle of activity with the aim of producing an artefact. In this case, the product is a mathematics lesson in which iPads are used to inform or facilitate a formative assessment process. The cyclical development process involves several stages to design, test, obtain feedback, reflect and redesign the lesson (Gravemeijer and Cobb, 2006, Swan, 2014). Through various iterations, the designs are systematically reviewed and improved in a process of progressive refinement (Brown, 1992). Typically, the intention is to produce a well-tested exemplar task or lesson through a rigorous reflexive process but, in this project, the emphasis is on exploring different ways of using iPads in the lesson through successive iterations, rather than producing an exemplar lesson. Involving teachers in collaborative discussions as codesigners during this design research process provides opportunities for professional learning in a social context where knowledge is shared between group members and also with researchers.

Since such design experiments are a fusion of research and practice (Burkhardt and Schoenfeld, 2003) there is a need to conduct trials and observe the 'learning phenomena' (Collins et al., 2004) in real situations. The cyclical design process therefore includes the use of designed tasks or lessons by teachers in classroom situations, so that observations, reflection and analysis can be carried out of the theoretically conceived tool in practical use. By working with teachers in both the design and implementation stages, a shared understanding of the aims is developed and the teachers' theoretical learning during the design work is directly linked to actual professional practice.

These lessons are, however, dependent on the existing level of the teachers' knowledge and skills with iPad technology. In this project, the research team offer 
evidence-based understanding of formative assessment and its implementation in the classroom from prior studies, but there is a dependency on the technical knowledge of the teachers, so that the designed lessons can be implemented in their own classroom situations without extensive additional technical training. The teachers' knowledgesharing regarding iPad technology is therefore essential to the success of the research project and their contributions to discussions about lesson designs are a valuable part of the process. This influences the nature of the collaborative partnership and provides opportunities for greater teacher participation in the design research process than might otherwise have taken place.

There are three distinctive features of this design research approach that are important to consider with respect to the professional learning of these teachers:

- the emphasis on experimentation and inquiry;

- the reciprocal knowledge-sharing with researchers;

- the extension of collaboration across both design and implementation stages.

How teachers engage with these elements of the research process will influence the nature and extent of their individual professional learning, but their interactions as a group are particularly important in the development of shared learning experiences.

\section{The design project}

The second aspect to consider is how the exploration of specific aims for the design project might affect the professional learning of the participating teachers. The intention of the project was to gain a better understanding of how iPad technology could contribute to formative assessment processes by studying the interactions of teacher, technology and student (Dalby \& Swan, 2019). It could be reasonably expected 
therefore that the teachers would develop some theoretical and practical classroombased knowledge in these areas from participating in the study.

Their prior knowledge of iPad technology and formative assessment also becomes important though, since it determines individual starting points and possible learning trajectories. Individual teachers with different levels of prior knowledge about iPad technology or formative assessment may have more, or less, to learn from the project. Their existing knowledge also affects their contributions to discussions, thereby affecting the nature of their involvement in this element of the collaborative activity. In these ways the two areas of knowledge, iPad technology and formative assessment, help define the focus for collaborative discussion during the project, but may also act as a constraint, determining boundaries for the knowledge exchanges that take place and thereby affecting the capacity for professional learning generated directly from engaging with the project aims.

\section{Literature review}

Having briefly examined the context for this study, we now consider the professional learning that takes place. In the following discussion, different aspects are explored in more detail but, the starting point, for the purposes of this study, is that professional learning is any form of activity that allows teachers to think about and gain better understanding of their professional practice in a way that can facilitate a change in practice (Timperley et al., 2008).

Fundamentally, any programme of professional development is concerned with facilitating change, namely a change in teacher knowledge, and therefore involves a process of learning (Avalos, 2011, Kennedy, 2016). Professional learning for teachers is not just about gaining theoretical knowledge but about developing practice (Timperley 
et al., 2008) and this may require a shift in thinking about what teacher learning actually involves, towards a view that is centred on effective enactment in the workplace setting (Fullan, 2007). Such professional learning may be considered as a change in practice and thinking that results from meaningful interaction (Kelchtermans, 2004). This fusion of theory and practice in professional learning is, however, problematic. Changing perspectives on what constitutes learning gives rise to different conceptualisations of professional learning (Matos et al., 2009, Mockler, 2012, Kennedy, 2016) and a variety of possible models for developing professional practice

The distinction between 'learning as acquisition' and 'learning as participation' (Sfard, 1998) emphasises the difference between a passive transfer of learning (acquisition) and active forms which take place in social situations (participation). Associated views of knowledge and 'knowing' suggest that knowledge can be conceptualised as either a commodity that is acquired, or as the result of active participation, communication and 'belonging' in a social situation. The latter view of knowledge, as socially constructed through participation, is often conceptualised as a process of identity-shaping and 'becoming' (Wenger, 1999) rather than simply cognitive activity and this concept of learning as a professional underpins the approach in this study. The nature of the active participation of the teachers is, therefore, a key consideration but their prior professional knowledge and practice provide the contextual background for an on-going process of professional learning.

For the development of technical and professional practice there is a need for 'knowing how' rather than simply 'knowing that' (Winch, 2013). Professional or vocational competence may be considered as fundamentally the exercise of technique, or skill, in a social environment but opportunities for knowledge creation and learning within the workplace vary (Fuller and Unwin, 2007). Teachers need to develop a 
conceptual understanding of different pedagogies but, in conjunction with classroom enactment, they should acquire a form of 'know how' that fuses theory and practice in a social context (Winch, 2013). Opportunities for the expansion of 'know how' would therefore appear to be essential for the effective professional development of teachers.

The process of learning in and from practice is important in professional development (Matos et al., 2009) and reference has been made to three specific types of knowledge: knowledge for practice; knowledge in practice and knowledge of practice. (Cochran-Smith and Lytle, 1999, Dana and Yendol-Hoppey, 2008). 'Knowledge for practice' involves knowing about how to teach and is mainly gained from instruction in various forms, whilst 'knowledge in practice' is constructed through the exploration of ideas in the classroom (Dana and Yendol-Hoppey, 2008). Both of these have value but are considered less effective in the process of changing practice than 'knowledge of practice', which is gained through teachers engaging in deeper reflection, questioning and systematic study of their classroom practice. The nature of the participatory opportunities offered by the study is therefore important. By placing teachers in particular roles within the social situations facilitated by the study, knowledge of different types could be constructed in the development of professional learning.

In this study the main focus is on examining the process of professional learning rather than evaluating the long-term effects, which would be unrealistic considering the small groups and limited timescale. It is worth noting however that evaluating the effectiveness of professional learning is problematic, due to differences in the way 'effectiveness' is interpreted and how it can actually be measured. For example, Timperley et al (2008) consider evidence of positive outcomes for students and the nature of the professional development as measures of effectiveness, whilst Guskey (2000) lists a series of possible measures, suggesting that the impact on student learning 
is often the most important in education. This forms a recurring theme as a measure of effective professional learning (Guskey, 2000, Bolam et al., 2005, Timperley et al., 2008, Kennedy, 2016) which is not surprising since this is, arguably, the primary purpose of the education system. It is also the primary concern of teachers, who are expected to learn and improve their teaching skills through participation in professional development. By focussing on how groups of teachers learn together the research contributes to an understanding of professional learning and highlights processes that may lead to better student outcomes but does not extend to a formal evaluation of the impact on student learning.

\section{Professional learning communities}

Research evidence suggests that active participation in professional learning communities is more effective than using the traditional model of individual theorybased instruction (Matos et al., 2009, Ermeling, 2010, O.E.C.D., 2013)but also raises two important issues. Firstly, the nature of the participation of individual teachers is essential to the functioning and effectiveness of the professional learning community. Secondly, how collective teacher activity is bound together by a clear purpose, shared aims and vision is an important consideration (DuFour and Eaker, 2009).In this study we therefore consider the nature of teacher participation and how this contributes to the development of professional learning communities in addition to the effects on the professional learning of individual teachers.

Fullan (2007) suggests that professional learning should be centred on teachers' practice in their workplace, involving the de-privatisation of classroom practice and a collaborative approach. Rather than classroom practice being an individual activity enclosed in a classroom, de-privatisation allows for greater transparency, awareness and discussion of colleagues' work practices. Similar themes appear in other literature (e.g. 
Vescio et al., 2008, Slavit and Nelson, 2010) and highlight the effectiveness of professional development models that combine collaborative teacher activity with a strong focus on classroom practice. Recent research evidence supports the view that collaborative teacher learning in professional learning communities provides a 'successful' model for sustainable teacher development (Dana and Yendol-Hoppey, 2008, Matos et al., 2009, Horn and Little, 2010, O.E.C.D., 2013), particularly when focused on measures of effectiveness concerned with student achievement and professional learning (Bolam et al., 2005). Despite variations in views of how such communities are constituted (Stoll et al., 2006) this approach to professional development promises more than traditional methods (Ermeling, 2010). The intention and purpose of the learning community needs, however, to be appropriately focussed on achieving improvement through changes in practice and should be based on a realistic model with clear aims (DuFour, 2007).

The concept of a professional learning community has two distinct roots, with some commonality but a fundamental difference in focus. Based on Senge's (2006) concept of a 'learning organisation' from a business perspective, some would view a professional learning community as a having school-wide membership and a characteristic collaborative culture (Fullan, 1993). Alternatively, the starting point is the concept of a 'community of practice' (Lave and Wenger, 1991, Wenger, 1999) or a 'learning community' (Wenger and Snyder, 2000) which is formed when a group of people are informally bound together by mutual engagement, shared experience and passion for a joint enterprise (Wenger, 1999). Such learning communities have a social dimension so that teachers are expected to regularly communicate, collaborate, share knowledge and give social support to each other (Krainer, 2003). Collaboration and reflection on practice are common themes in both these conceptual foundations but the 
first arises from considerations of organisational change and the second from a model of apprenticeship, in which a group of teachers with a shared aim develop professional knowledge. For this study we will only be concerned with small groups of mathematics teachers in schools and the fundamental concept of a community of practice becomes more relevant than the school-wide organisational view. The orientation of the institution towards learning and the coherence of group aims with school goals is however still influential. Opportunities for professional learning may well be dependent on whether the workplace constitutes what Fuller and Unwin (2007) refer to as an 'expansive' or 'restrictive' learning environment.

In a professional learning community we would expect the three main elements of a community of practice to be evidenced: a clear domain, a collaborative community and shared practice (Wenger, 1999, Wenger, 2011). Individual teachers may be positioned initially with their community of practice as experts relative to their colleagues, or as legitimate peripheral members who are moving towards full membership as their expertise develops (Lave and Wenger, 1991). By basing the study on this fundamental concept, the positioning, relationships and interactions between members become central to the study. The roles of individual members and actions taken by more experienced teachers within the group are factors important to the success of professional learning communities (Lieberman and Pointer Mace, 2009) and the approach taken will allow for a close examination of how these factors contribute to the early stages of development of teacher groups into similar learning communities.

The development of professional learning communities of this type may however be incomplete as an effective model for teacher development without further focussed activity. Dimmock (2017) proposes that the missing element is that such professional learning communities need to be research-engaged. The processes in this 
study of involving teachers in the research are a vital part of the collaborative activity and it seems appropriate to examine what part this played in the professional learning that took place. Five characteristics commonly identified as important in early literature will be useful for comparison with emerging characteristics of the teacher groups: shared values; collective responsibility; collaboration; reflection and inquiry; and group and individual learning (Stoll et al., 2006). Bolam et al. (2005) however add three further common features, which are primarily concerned with relationships. The importance of teachers' positioning and relationships in collective participation has already been highlighted but these social relationships also connect characteristics of professional learning communities with cultural values in this situated learning situation. For example, if effective de-privatisation of practice takes place (Fullan, 2007, Vescio et al., 2008) then this activity is more likely to be successful in a culture of mutual trust and respect (Bolam et al., 2005). The question to be explored in this paper is whether the opportunities provided through the distinctive collaborative design research approach can successfully facilitate the development of any of these characteristics and, if so, what elements of the process are most influential in providing favourable conditions for the growth of these features. In addition to interviewing the teachers regarding their professional learning, it is also important to observe the relationships and interactions between individuals in order to study the collaborative process and group characteristics develop.

\section{Methodology}

The main research findings for this project are reported elsewhere (Dalby and Swan, 2019) and therefore only the methods relevant to this study of the teachers' professional learning are described here. However, the iterative design cycle described earlier remains an essential part of the process: lesson design; classroom trial and observation; 
feedback; reflection; revisions to the design (Gravemeijer and Cobb, 2006, Swan, 2014). This cycle was repeated three times for each designed lesson, with a different teacher responsible for implementing the lesson in one of their own classrooms, within each cycle. The first cycle involved a substantial amount of planning, which took place over several weeks but subsequent cycles were usually completed with a week.

Members of the research team met with the teacher groups to facilitate the lesson planning and supported them through this process. The researchers then carried out observations, in pairs, of each lesson and one of the three versions of each lesson was video-recorded to facilitate more detailed analysis. Discussions took place with the teachers in between each lesson within a cycle to give feedback and consider revisions before the next iteration. Interviews were carried out with each of the participating teachers at the end of the design project and these were used, in conjunction with the lesson observations and other field notes, to explore the professional learning of these teachers during the design research process.

Three schools in the Midlands of England were involved in the project and within each school, a group of three teachers worked with the research team to develop three lessons over a period of around seven months. This was a project funded by the European Union (see Acknowledgements) and the teachers participated on a voluntary basis. Ethical approval was gained from the university and the relevant informed consents obtained from teachers and their students.

Each of these teachers groups and their professional learning journeys became a case study. For the purposes of this paper, we are only concerned with a comparison between two of these cases, which were both secondary comprehensive schools of similar size. Both were non-selective but with streamed classes for mathematics and had similar grading from their most recent external inspections. Ipads were available in both 
schools for student use and the teachers had some technical expertise with these before commencing the research.

Focussing on just two case studies provides the opportunity for a detailed, indepth examination of a singularity in a natural setting which has justifiable research value (Bogdan and Biklen, 1992, Bassey, 1999). By using qualitative data from different sources (paired lesson observations, observations of meetings, teacher interviews) and comparing the two cases, the credibility is strengthened (Yin, 2009).

Since the data were entirely qualitative, the initial analysis was carried out using a process of open coding to identify key themes. Emerging themes from teacher interviews were compared to lesson observations and notes from meetings to ensure triangulation of data from different sources. These themes were then re-examined in relation to Wenger's (2011) features of communities of practice: domain, community and practice. Emerging characteristics of these teacher groups were identified and then compared to the five common characteristics of professional learning communities (Stoll et al., 2006). Case studies of teacher groups and their professional learning were developed and a comparative analysis of these cases was carried out.

\section{Results and analysis}

Although there is naturally some overlap, the results and analysis will be presented here in a similar order to the research questions. Results concerning individual professional learning will be followed by a consideration of collective professional learning. An analysis will then be presented of the characteristics of professional learning communities that developed within these teacher groups. Finally some evidence will be examined concerning the specific features of the research project that were instrumental in teacher development. 
Clear evidence of individual professional learning as a result of participation in the research project was provided from teachers' interviews and observations of their meetings. Teachers identified two main areas of individual learning:

- technical understanding of specific uses of iPads and software;

- pedagogical adjustments that help facilitate formative assessment processes, with or without iPads.

These areas are not surprising, given the focus of the research project, but do highlight how professional learning was strongly connected to classroom practice and 'know how' (Winch, 2013) rather than theoretical knowledge (Timperley et al, 2008).

Individual knowledge gains showed some variation but were often linked by teachers to the opportunities for collaboration within the project. This included collaborative work with their colleagues to design or refine lessons, as well as the design activity and shared reflections on lessons that took place with researchers.

Teachers explained that the time spent working together on lessons had been particularly valuable, since this was an activity that rarely featured in their normal way of working, mainly due to time pressures. Working together in small collaborative groups with a shared aim and a focus, even over the short period of time for this research project, provided a stark contrast when compared to their normal day-to-day interaction. The research project provided a reason for collaborative activity even when the researchers were not present. Furthermore, a mutual commitment to the design research activity from these teacher groups led to the sharing of ideas and a deprivatisation of practice (Fullan, 2007, Vescio et al., 2008) that was difficult to achieve within their normal working routines. 
Alongside the importance of collaboration, two additional themes with respect to individual professional learning emerged strongly. Data from observations of the design process and the lessons showed how active participation in the research prompted teachers to adopt an inquiry approach to both lesson design and implementation. The intention for this project was to explore and innovate when using technology within mathematics lessons so developing an inquiry approach in the planning process was fundamental. Discussions with researchers encouraged teachers to reflect on the lessons and engage in questioning about lesson designs. Most individual teachers readily adopted this inquiry approach, becoming experimental with different uses of technology rather electing to implement 'safe' options. The freedom to experiment, endorsed by researchers, within a mutually supportive community with a shared aim, provided an environment for inquiry approaches to flourish.

The knowledge-sharing aspect of the research design also emerged as a significant opportunity which facilitated individual professional learning. Differences in knowledge specialisms between teachers and researchers led to a pragmatic shared approach regarding individual contributions to lesson designs, rather than the design being researcher-led. In this way, two central areas of knowledge for the research project (using iPad technology and formative assessment) were integrated in the design process through a negotiation of how technology and formative assessment could be combined in effective classroom learning. This enabled teachers to explore and extend their use of technology in the classroom but also gain understanding of the associated pedagogical approaches that would enhance formative assessment and lead to more effective student learning. Involvement in the research, as suggested by Dimmock (2016), was a key aspect of teacher activity that facilitated professional learning for individuals within these groups. 
These three themes are all linked to the design research approach and indicate opportunities for individual professional learning within the research activities. In contrast, observations and interviews suggested three characteristics connected to the aims of the research project that might act as constraints on the individual professional learning of some teachers.

The project aims usefully indicated the boundaries for the research activity and defined the research domain but these also resulted in unhelpful constraints on individual professional learning for some teachers. Although there were benefits in having a clear focus for the research activity, observations of lessons suggested that this emphasis sometimes caused other pedagogical issues to be neglected. Similarly, the knowledge priorities suggested by the research project aims constrained the progress of some teachers due to their different starting points. There was evidence that individuals with less prior knowledge of the areas prioritised, compared to others in the same teacher group, made less progress. Thirdly, the division of responsibility between teachers and researchers provided opportunities for some individual teachers to become deeply involved in the research project but also resulted in constraints on the involvement of others. For example, individual teachers' with strong technical knowledge were particularly valuable to this research project and readily engaged in discussion about the integration of technology, whilst those with less secure technical understanding took a more peripheral position in these discussions. These affordances and constraints are summarised in Figure 1. 


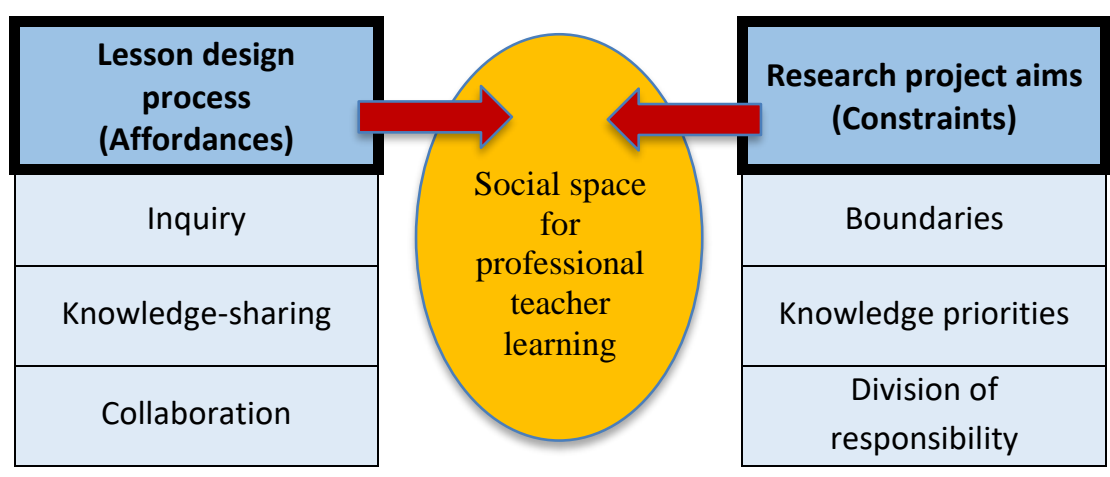

Figure 1. Affordances and constraints of the collaborative research activity.

This representation of the affordances and constraints provides an analytic tool to view the potential for individual professional learning associated with participation in this research project. With the small number of teachers involved, this cannot be interpreted as a reliable or complete summary but offers a simple framework for consideration of the potential opportunities within a research project. In this case, the distinctive characteristics of the design research process provide opportunities for individual teachers to collaborate, share thinking and engage in inquiry, whilst the project aims sometimes constrains individual professional learning, due to the type of knowledge that is prioritised and the division of responsibility within the collaboration.

These themes are important for identifying the potential for individual professional learning but they are also significant in the development of collective professional learning. A comparison to Wenger's (2011) three broad features of a community of practice (See Table 1), suggests that aspects of both the lesson design process, alongside the research project aims, contribute to the development of group characteristics.

In this study, however, one case study group developed into a more functional and effective professional learning community than the other. In this group, one teacher reported that these lessons were the 'best lessons we have taught all year' (School A), 
implying both teacher satisfaction and an anticipated positive effect on student learning. Although the effectiveness of professional learning is only measureable qualitatively from teachers' responses in this study, the extent to which this group exhibited shared ownership and satisfaction with the lessons was evidenced strongly in their interviews.

A small set of characteristics also emerge from the analysis, for which clear differences between the two cases can be identified (See Table 2). These characteristics show some connection to the features of effective professional learning communities described earlier (Stoll et al., 2006, Dimmock, 2016) but highlight several factors that contribute to these features.

Firstly, the teachers in these case studies approached the research project with their own personal interests as well as some shared group aims, but the connecting of these was important. Early negotiation of shared aims that had a focus on learning seemed to make it easier later to develop the group into an effective professional learning community. There were however some pre-conditions that may have been influential. Although both schools supported the used of digital technology and had iPads available, the school aims of the more effective professional learning community gave technology a high priority. Levels of prior technical knowledge and skills within the group became important for several reasons. Teachers who were confident with the use of technology in their lessons quickly became more actively engaged than those with less expertise, which affected their positioning within the small developing professional learning communities. In School A, teachers had similar levels of confidence initially, although different knowledge, but there was mutual respect and shared responsibility for the lesson design work. In School B, the teacher with least technical knowledge tended to take a more peripheral role and, although there was evidence they intended to learn and become more central in their community of 
practice, this was not achieved. Their initial position of legitimate peripheral participation (Lave and Wenger, 1991), eventually became one of marginalisation over the course of the project. Their lack of confidence with technology was a restraint that limited their involvement in lesson design and resulted in minimal gains in professional knowledge. Colleagues were supportive in terms of assisting their colleague with the technical skills but did not allow sufficient agency in the design phase for this teacher to move into a greater participatory role.

In both schools, a group leader facilitated discussions between teachers but communication was noticeably more regular in School A. This enabled deeper discussions to take place and encouraged a higher level of involvement from the other two group members.

Together, these differences in the development of the two teacher groups indicate some key areas where effective leadership of a teacher group can encourage the growth of a professional learning community. Although the evidence from these two contrasting cases is limited, there are indications that leaders who encourage the group to negotiate shared aims, communicate regularly and divide responsibilities are more likely to see the group develop some of the key characteristics of a professional learning community.

Finally, it is important to consider the influences on individual and collective learning that arise from the situation of this teacher group activity within the broader context of collaborative work with researchers. In the first stage of the lesson design process, the way of working involved collaboration and knowledge sharing between teachers and researchers as well as within teacher groups. During the classroom trials, however, the teachers took an 'insider' role (Dana and Yendol-Hoppey, 2008) and their teaching of the designed lessons was instrumental in developing 'knowledge in 
practice'. Feedback from the researchers following lessons involved further knowledgesharing but this then led to the reflection stage where 'knowledge of practice' was further developed. Figure 2 shows how the design research cycle, which commences with an initial design and follows several iterations as the design is trialled and revised, is linked to a cycle of professional learning at four stages (design/re-design, trial, feedback, reflection). Specific opportunities for teachers to construct knowledge of different types are made available at each stage.

FFigu

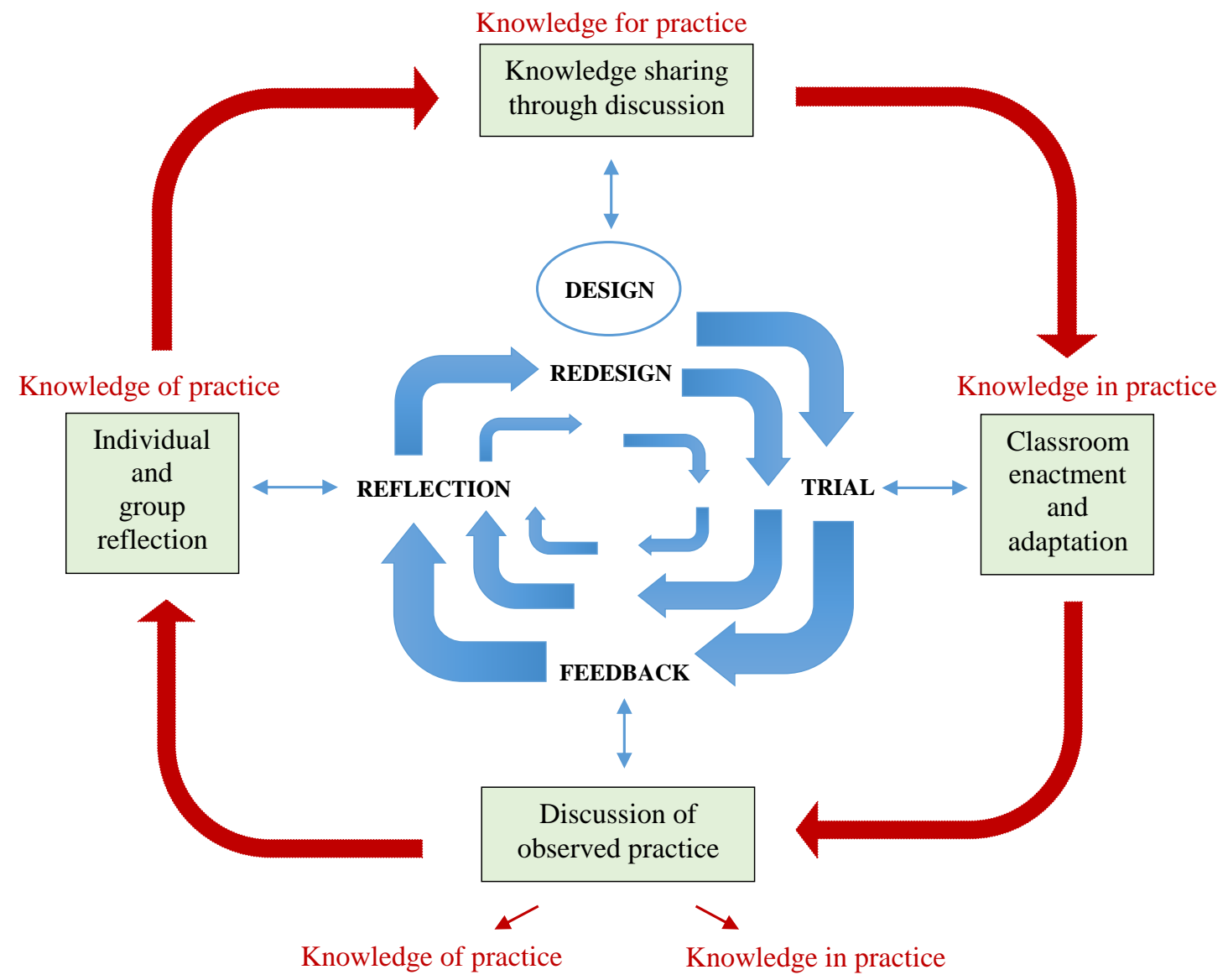

Figure 2. The design research cycle and professional learning.

In both our cases, teachers and researchers were involved in knowledge sharing through the collaborative design research activity and each party gained useful knowledge from these socially situated exchanges, with the interlinking of theory and 
practice being particularly important. Although there were exchanges in the design research cycle that only contributed to teachers' 'know-that', such knowledge was often linked to classroom implementation in the next iteration and trial of the lesson. In this way theoretical ideas were used and experienced in classroom situations, thereby opening up opportunities for increasing 'knowledge in practice' (Cochran-Smith and Lytle, 1999). As the cycle progresses, teachers are involved in reflective discussions about their enactments of lesson designs and develop a more critical approach which contributes to a deeper 'knowledge of practice' (Cochran-Smith and Lytle, 1999, Dana and Yendol-Hoppey, 2008). In this way, interaction between teachers and researcher within the design research cycle provides specific opportunities for knowledge creation (Wiliam, 2002) that may not be present in alternative research designs.

\section{Conclusions}

The individual professional learning journeys of the teachers in this study were interwoven with those of their colleagues but also influenced by their engagement in the design research (Dimmock, 2016) and the nature of the activity in which they were involved, including their interaction with researchers. Individual expectations of developing their professional practice were fused together by participating in the study into a shared purpose, indicating useful benefits for collective professional learning beyond the immediate project aim.

The lesson design process and the aims of the design project provided both affordances and constraints for individual professional learning but also contributed to the development of key features of professional learning communities. Anticipating and balancing such affordances and constraints for a predetermined professional learning outcome is a challenge that needs careful consideration if collaborative research is to achieve more specific aims. In this study, teacher inquiry and collective reflection were 
promoted due to the experimental purpose of the design research approach. This added to 'knowledge of practice' and increased the capacity of these teachers to research their own practice. A focus for knowledge sharing was provided by the research project aims, thereby creating space for professional learning in the use of digital technology and formative assessment.

Involvement in activity framed by these two elements, the lesson design process and research aims, provided teachers with rich opportunities for knowledge creation through a process with similar features to the key characteristics of effective professional learning (Stoll et al., 2006, Dimmock, 2016). This further supports the view that participation in collaborative research has potential for effective professional learning, although the processes and boundaries require more extensive exploration than this limited study can provide.

In this study, the interlinked components of the design project were fundamental to the way of working together that developed and to the professional learning of the teachers. Through working together collaboratively with a shared aim, teacher groups could develop into small professional learning communities where the teachers had the opportunity to develop 'knowledge in practice' of value for the research project, whilst also increasing their own 'knowledge of practice' in a specific area.. The effectiveness of these groups as professional learning communities was, however, influenced by the leadership of the group, the frequency of communication between members and the level of ownership of shared aims. The prior technical knowledge of individuals also determined their positioning within the learning community and their resulting individual learning.

The findings provide evidence that the participation of teachers in collaborative research can provide valuable opportunities for professional learning but the 
professional knowledge gained depends on the research project aims, the methods and the nature of the collaborative activity between teachers. These features affect the way in which the teacher groups function and the characteristics they develop. The findings support the view that the professional learning journeys of teachers can benefit from involvement in practice-based research (Dimmock, 2016) in collaborative groups within their own schools, but that this not an automatic consequence. Professional learning through participation in collaborative research therefore needs to be carefully designed, bearing in mind the influences that will be instrumental, if specific knowledge gains or changes in practice are to be achieved.

The study involves a comparison of two cases in similar contexts and is therefore is limited by its scale, the specific nature of the design research activity and the context in which collaborative activity took place. Further examination of the professional learning that develops from involvement within other research projects in other settings is needed to determine any wider principles. This study does, however, provide some clear indications of the conditions favourable for professional learning that may be developed during participation in research and how the early steps towards becoming a professional learning community might be established.

\section{Acknowledgments}

This research project has received funding from the European Union's Seventh Framework Programme under grant agreement no 612337.

\section{References}

Avalos, B., 2011. Teacher professional development in Teaching and Teacher Education over ten years. Teaching and teacher education, 27, 10-20.

Bassey, M., 1999. Case study research in educational settings. Buckingham: Open University Press.

Bogdan, R.C. \& Biklen, S.K., 1992. Qualitative research for education, 2nd ed. Needham Heights, MA: Simon and Schuster. 
Bolam, R., Mc Mahon, A., Stoll, L., Thomas, S., Wallace, M., Greenwood, A. \& Smith, M., 2005. Creating and sustaining effective professional learning communities. Bristol: University of Bristol, Department of Education and Skills.

Brown, A.L., 1992. Design experiments: Theoretical and methodological challenges in creating complex interventions in classroom settings. The journal of the learning sciences, 2, 141-178.

Burkhardt, H. \& Schoenfeld, A.H., 2003. Improving educational research: Toward a more useful, more influential, and better-funded enterprise. Educational Researcher, 32, 3-14.

Cochran-Smith, M. \& Lytle, S.L., 1999. Relationships of knowledge and practice: Teacher learning in communities. Review of research in education, 24, 249-305.

Cochran-Smith, M. \& Zeichner, K.M., 2009. Studying teacher education: The report of the AERA panel on research and teacher education. New Jersey: Lawrence Erlbaum Associates.

Collins, A., Joseph, D. \& Bielaczyc, K., 2004. Design research: Theoretical and methodological issues. The journal of the learning sciences, 13, 15-42.

Dalby, D. \& Swan, M., 2019. Using digital technology to enhance formative assessment in mathematics classrooms. British Journal of Educational Technology, 50, 832845.

Dana, N.F. \& Yendol-Hoppey, D., 2008. The reflective educator's guide to professional development: Coaching inquiry-oriented learning communities. Thousand Oaks, CA.: Corwin Press.

Day, C. \& Sachs, J., 2004. Professionalism, performativity and empowerment: discourses in the politics, policies and purposes of continuing professional development. In C. Day \& J. Sachs (eds.) International handbook on the continuing professional development of teachers. Open University Press, 3-32.

Dimmock, C., 2016. Conceptualising the research-practice-professional development nexus: mobilising schools as 'research-engaged'professional learning communities. Professional Development in Education, 42, 36-53.

Dufour, R., 2007. Professional learning communities: A bandwagon, an idea worth considering, or our best hope for high levels of learning? Middle School Journal, 39, 4-8.

Dufour, R. \& Eaker, R., 2009. On common ground: The power of professional learning communities: Solution Tree Press.

Ermeling, B.A., 2010. Tracing the effects of teacher inquiry on classroom practice. Teaching and Teacher Education, 26, 377-388.

Fraser, C., Kennedy, A. \& Mckinney, S., 2007. Teachers' continuing professional development: Contested concepts, understandings and models. Journal of inservice education, 33, 153-169.

Fullan, M., 1993. Change forces: Probing the depths of educational reform. London: Falmer Press.

Fullan, M., 2007. Change the terms for teacher learning. Journal of staff development, 28, 35-36.

Fuller, A. \& Unwin, L., 2007. Creating and using knowledge: an analysis of the differentiated nature of workplace learning environments. British Educational Research Journal, 33, 743-759.

Gravemeijer, K. \& Cobb, P., 2006. Design research from a learning design perspective. In J. Van Den Akker, K. Gravemeijer, S. Mckenney \& N. Nieveen (eds.) Educational design research. Abingdon: Routledge, 17-51. 
Guskey, T.R., 1994. Professional development in education: in search of the optimal mix. Annual Meeting of the American Educational Research Association. New Orleans, LA.

Guskey, T.R., 2000. Evaluating professional development. Thousand Oaks, CA.: Corwin Press.

Horn, I.S. \& Little, J.W., 2010. Attending to problems of practice: Routines and resources for professional learning in teachers' workplace interactions. American Educational Research Journal, 47, 181-217.

Kelchtermans, G., 2004. CPD for professional renewal: moving beyond knowledge for practice. In C. Day \& J. Sachs (eds.) International handbook on the continuing professional development of teachers. 217-237.

Kennedy, A., 2005. Models of continuing professional development: a framework for analysis. Journal of in-service education, 31, 235-250.

Kennedy, M.M., 2016. How does professional development improve teaching? Review of educational research, 86, 945-980.

Krainer, K., 2003. Teams, communities \& networks. Journal of Mathematics Teacher Education, 6, 93-105.

Lave, J. \& Wenger, E., 1991. Situated learning: Legitimate peripheral participation Cambridge: Cambridge University Press.

Lieberman, A. \& Pointer Mace, D.H., 2009. The role of 'accomplished teachers' in professional learning communities: Uncovering practice and enabling leadership. Teachers and Teaching: theory and practice, 15, 459-470.

Matos, J.F., Powell, A., Sztajn, P., Ejersbø, L., Hovermill, J. \& Matos, J.F., 2009. Mathematics teachers' professional development: Processes of learning in and from practice. In R. Even \& D.L. Ball (eds.) The professional education and development of teachers of mathematics. US: Springer, 167-183.

Mockler, N., 2012. Teacher Professional Learning in a Neoliberal Age: Audit, Professionalism and Identity. Australian Journal of Teacher Education, 38, 3547.

O.E.C.D., 2013. Teaching in Focus: Fostering teacher learning communities [online]. http://www.oecd.org/education/school/TiF\%20(2013)--N\%C2\%B04\%20(eng)-v2.pdf [Accessed Access Date 2018].

Senge, P.M., 2006. The fifth discipline: The art and practice of the learning organization, 2nd ed. London: Random House Business Books.

Sfard, A., 1998. On two metaphors for learning and the dangers of choosing just one. Educational researcher, 27, 4-13.

Slavit, D. \& Nelson, T.H., 2010. Collaborative teacher inquiry as a tool for building theory on the development and use of rich mathematical tasks. Journal of Mathematics Teacher Education, 13, 201-221.

Stoll, L., Bolam, R., Mcmahon, A., Wallace, M. \& Thomas, S., 2006. Professional learning communities: A review of the literature. Journal of educational change, 7, 221-258.

Swan, M., 2014. Design research in mathematics education. In S. Lerman (ed.) Encyclopedia of mathematics education. Netherlands: Springer, 148-152.

Timperley, H., Wilson, A., Barrar, H. \& Fung, I., 2008. Teacher professional learning and development. Brussels: International Academy of Education.

Vescio, V., Ross, D. \& Adams, A., 2008. A review of research on the impact of professional learning communities on teaching practice and student learning. Teaching and teacher education, 24, 80-91. 
Villegas-Reimers, E., 2003. Teacher professional development: an international review of the literature. Paris: International Institute for Educational Planning.

Wenger, E.C., 1999. Communities of Practice: Learning , Meaning and Identity. Cambridge: Cambridge University Press.

Wenger, E.C., 2011. Communities of practice: A brief introduction. [online]. https://scholarsbank.uoregon.edu/xmlui/bitstream/handle/1794/11736/A\%20brie f\%20introduction $\% 20$ to $\% 20$ CoP.pdf? sequence $=1 \&$ is Allowed $=y$ [Accessed Access Date

Wenger, E.C. \& Snyder, W.M., 2000. Communities of practice: The organizational frontier. Harvard business review, 78, 139-146.

Wiliam, D., 2002. Linking Research and Practice: Knowledge Transfer or Knowledge Creation? PME. Athens, GA.

Winch, C., 2013. Three Different Conceptions of Know-How and their Relevance to Professional and Vocational Education. Journal of Philosophy of Education, 47, 281-298.

Yin, R.K., 2009. Case study research: Design and methods, 4th ed. Thousand Oaks, CA: Sage. 
Table 1. Contributions to a community of practice from components of the research activity.

\begin{tabular}{|c|c|c|c|}
\hline \multirow[b]{2}{*}{ Sources } & \multicolumn{3}{|c|}{ Features of a community of practice } \\
\hline & Shared domain & $\begin{array}{c}\text { Collaborative } \\
\text { community }\end{array}$ & Shared practice \\
\hline $\begin{array}{l}\text { Lesson design } \\
\text { process }\end{array}$ & $\begin{array}{l}\text { Teachers are } \\
\text { involved in a shared } \\
\text { activity to design } \\
\text { and trial lessons. }\end{array}$ & $\begin{array}{l}\text { Teachers work } \\
\text { together } \\
\text { collaboratively in } \\
\text { lesson design with } \\
\text { colleagues. }\end{array}$ & $\begin{array}{l}\text { Teachers share prior } \\
\text { knowledge to } \\
\text { inform lesson } \\
\text { designs and their } \\
\text { reflections on } \\
\text { classroom } \\
\text { implementation. }\end{array}$ \\
\hline $\begin{array}{l}\text { Research } \\
\text { project aims }\end{array}$ & $\begin{array}{l}\text { Teachers adopt a } \\
\text { shared focus on } \\
\text { using digital } \\
\text { technology in } \\
\text { formative } \\
\text { assessment. }\end{array}$ & $\begin{array}{l}\text { Teachers work } \\
\text { collaboratively in } \\
\text { order to achieve the } \\
\text { project aims. }\end{array}$ & $\begin{array}{l}\text { Aims encourage } \\
\text { sharing of } \\
\text { alternative } \\
\text { pedagogical } \\
\text { approaches and } \\
\text { alternative methods. }\end{array}$ \\
\hline
\end{tabular}


Table 2. Comparison of characteristics between cases.

\begin{tabular}{|l|l|l|}
\hline $\begin{array}{l}\text { Characteristics of } \\
\text { teacher group }\end{array}$ & School A & School B \\
\hline Individual aims & $\begin{array}{l}\text { Some similarity in individual aims } \\
\text { regarding developing the effective } \\
\text { use of iPads in mathematics } \\
\text { teaching. }\end{array}$ & $\begin{array}{l}\text { Varied interests of individuals in } \\
\text { participating in the research. }\end{array}$ \\
\hline Shared aims & $\begin{array}{l}\text { The facilitator within the group } \\
\text { negotiates well-defined, shared } \\
\text { aims. The group focus is on } \\
\text { improving student learning. }\end{array}$ & $\begin{array}{l}\text { Shared aims are less clearly defined } \\
\text { and individuals have different aims. } \\
\text { The group focus is on the } \\
\text { technology. }\end{array}$ \\
\hline Technical & $\begin{array}{l}\text { All members are confident with } \\
\text { technology but specific technical } \\
\text { knowledge varies. }\end{array}$ & $\begin{array}{l}\text { Levels of confidence with } \\
\text { technology vary widely between } \\
\text { team members. }\end{array}$ \\
\hline Leadership & $\begin{array}{l}\text { The facilitator is the main contact } \\
\text { with researchers but } \\
\text { responsibilities and ideas for } \\
\text { lesson design are shared. }\end{array}$ & $\begin{array}{l}\text { The facilitator leads the group, } \\
\text { liaises with the researchers and } \\
\text { carries out most of the design } \\
\text { activity on behalf of the group. }\end{array}$ \\
\hline $\begin{array}{l}\text { Professional } \\
\text { relationships }\end{array}$ & $\begin{array}{l}\text { Built on existing collaborative } \\
\text { ways of working. }\end{array}$ & $\begin{array}{l}\text { Previously worked together as } \\
\text { individuals within part of a larger } \\
\text { team. }\end{array}$ \\
\hline Communication & $\begin{array}{l}\text { Frequent communication between } \\
\text { team members, although often } \\
\text { email rather than face to face. }\end{array}$ & $\begin{array}{l}\text { Infrequent communication between } \\
\text { members. }\end{array}$ \\
\hline
\end{tabular}


Figure 1. The affordance and constraints of the research design on individual professional teacher learning.

Figure 2. The design research cycle and associated elements of professional learning. 